\title{
Embedding eSkills in Initial Teacher Training
}

\section{Elaine Szpytma \\ Zip-E Consultancy EECETT}

\author{
Catherine Bone \\ JISC Regional Support Centre
}

\begin{abstract}
The decision to become a teacher is a noble and rewarding choice but it presents individuals with many challenges. Trainee teachers are often overwhelmed by the amount of knowledge they are expected to acquire in order to be an effective teacher. Embedding eSkills in Initial Teacher Training (ITT) aims to alleviate one of the challenges - that of integrating the effective use of technology into their teaching. By embedding eSkills into the teacher training process it is possible to build confidence in teachers and help them feel comfortable with the technology, in turn enabling them to identify when and where to use technology to enhance the learning process, a vital skill in $21^{\text {st }}$ century learning. This paper provides an overview of the eSkills programme and explains how it was embedded in ITT programmes.
\end{abstract}

\section{Key words}

ICT (Information and Communications Technology); IT (Information Technology); Initial Teacher Training; eSkills; elearning; Technology; Pedagogy; Learning; Teaching; DTTLS (Diploma in Teaching in the Lifelong Learning Sector).

\section{Introduction}

This paper focuses on the eSkills for e-Learning staff development programme and how it was effectively embedded in ITT. The paper draws on research carried out as part of a Masters dissertation and on the practical application of the eSkills programme in IT'T within a Higher Education Institute.

For the purposes of this paper, the e-learning definition used comes from the Joint Information Systems Committee (JISC) e-Learning Pedagogy Programme (2003: p. 15) where e-learning is defined as 'learning facilitated and supported through the use of information and communications technology (ICT)'.

The eSkills for e-Learning programme was originally developed by the JISC Regional Support Centre (RSC) Scotland South and West, and launched by RSC Eastern in 2008. The programme aimed to provide staff development managers with a free and effective e-learning staff development programme which, when delivered in-house, would enable staff to develop their skills and reach a confident level in order to use e-learning to enhance their teaching.

The eSkills programme consists of nine modules, outlined below and in more detail within Appendix 1:

- Module 1: An Introduction to e-learning

- Module 2: e-resources and copyright

- Module 3: Creating Interactive Resources (1) (Microsoft Word)

- Module 4: Designing an Inclusive Curriculum

- Module 5: Creating Interactive Resources (2) (Microsoft PowerPoint)

- Module 6: Online Communications and e-Tutoring

- Module 7: e-Assessment

- Module 8: Learning Platforms and Going Mobile

- Module 9: e-Safety and Safeguarding

The eSkills programme has been taken up by a number of institutions who delivered the programme to qualified teachers and also embedded it in their Diploma for Teaching in the Lifelong Learning Sector (DTLLS)/Certificate in Education (Cert Ed)/Postgraduate Certificate in Education (PGCE) courses; this paper focuses on how the eSkills programme was embedded within these courses.

\section{Context}

The White Paper Further Education: Raising Skills, Improving Life Chances published by the Department for Education and Skills (DfES, 2006: p. 8) highlighted the importance of 'making effective use of new technology' to improve teaching and learning. According to the Quality Assurance Agency for Higher Education (QAA, 2008: p. 12), 'e-learning has become firmly established as a core activity for many Higher Education institutions'.

The JISC Senior Management briefing paper, Tangible Benefits of e-Learning: Does Investment Yield Interest? (JISC, 2008: p. 2) stated, 'the kind of high quality, diverse, accessible, expanding Higher Education system desired by government and funders is no longer possible without e-learning'. Additionally, in their Statement of Policy (2009: p. 1), the Higher Education Funding Council for England (HEFCE) reflected on 'bow technology can support individual institutions in achieving some of their key strategic aims'.

Following research funded by JISC, the Responding to Learners Pack, Guide for Institutional Managers was produced and disseminated. The guide stated: 'many learners enter Further and Higher Education confident, positive and enthusiastic about their use of 
technology. Learners expect to be able to use institutional and personal technologies as soon as they arrive, and in a way that they find familiar (JISC, 2009: p. 2).

Government and institutional policy along with learner expectations have combined to exert considerable pressure on teaching staff to develop their e-learning skills. Numerous resources and an enormous amount of effort are expended each year within colleges and universities in providing staff with development opportunities which aim to empower them in order to fulfil these expectations. Whilst the importance of Continuing Professional Development (CPD) for established lecturers cannot be ignored, the importance of embedding e-learning development in ITT is vital to ensure confident professionals. It provides the opportunity for simultaneous bottom-up and top-down approaches to the development of e-learning.

\section{Embedding eSkills}

The eSkills materials are presented in a modular format and made available under the 'Creative Commons, Attribution-Share Alike' licence, enabling institutions to tailor the materials in ways which are most effective for them. The programme focused on pedagogy rather than technology. 'Giving practical guidance on the technologies and how they can be utilised in teaching and learning provides opportunities for teachers to be trained in the use of ICT' (Collis and Jung, 2003 as cited in Jung, 2005: p. 95), and provides opportunities for trainees to experiment with different approaches to using ICT in order to improve their pedagogical practice.

The pedagogy of using ICT to support teaching and learning is still evolving; current research supports the view that effective use of ICT to support teaching and learning involves combining new technologies with effective pedagogy (Jung, 2005) in order to develop purposeful use of technology to support learning. This requires teachers to use 'their subject expertise to obtain and select appropriate ICT resources to belp meet the learning objectives of a particular lesson' (Cox and Webb, 2004: p. 7). Alexander, as cited in Cox and Webb (2004: p. 16) suggests that 'pedagogical content knowledge refers to knowledge about a topic that enables improved teacbing of that discipline' - when making decisions about their use of ICT, teachers will need to use this subject knowledge in order to make informed decisions. As the pedagogical content knowledge between subjects will differ so will the use of ICT resources differ between subjects (Cox and Webb, 2004: p. 237; Cox, Webb et al 2004: p. 16). Referring to research conducted by Haddad (2003), Jung (2005: p. 95) suggests that ICT can 'change the way teachers teach', promoting a more student centred approach which in turn promotes thinking skills and collaborative learning. This view is supported by Hennessy et al (2003) who reported a shift in roles, with a less didactic approach being taken by teachers. Their findings suggest using ICT promoted a more collaborative approach to learning. Learners were encouraged to take responsibility for their own learning through participation and collaboration, with the teacher taking on the role of facilitator, providing support and guidance. They suggest that this required 'proactive and responsive strategies' by the teacher to 'monitor progress and maintain focus' (ibid: p. 4). However, research on the contribution of ICT to attainment (Cox and Webb, 2004) suggests that 'ICT is only effective when combined with good teaching' (ibid: p. 18). This view is supported by Higgins (2009) who found that learners' performance was improved where ICT was used effectively, suggesting that the difference in learner performance was due to the more innovative approaches applied by the teacher rather than the technology itself.

The Cert Ed/PGCE/DTLLS course consists of eight units of assessment

Year 1:

Unit 2 - Planning and Enabling Learning

Unit 4 - Enabling Learning and Assessment

Unit 5 - Theories and Principles of Planning and Enabling Learning

Unit 6 - Subject Specific Teaching

Year 2:

Unit 7 - Reflective Practice and Professional Development

Unit 8 - Curriculum Development for Inclusive Practice

Unit 9 - Wider Professional Practice

Option Unit - IT and the Teacher, Teacher as Researcher, Working with 14-19 Learners, Equality and Diversity

The table in Appendix 2 maps the eSkills modules to the DTLLS/Cert Ed/PGCE units.

The flexibility of the eSkills programme allows for key elements from each of the modules to be embedded across the two years of the Cert Ed course, but particularly in units 6 and 9 . By focusing on the pedagogy underpinning the use of technology, embedding the eSkills modules within ITT provides opportunities for trainees to improve their skills and confidence in using technology whilst developing their teaching skills. In order to plan an effective ICT-based learning environment requires complex pedagogical reasoning combined with an understanding of how ICT can support learning and instruction (Cox and Webb, 2004). In their studies, they found that teachers' beliefs in the value of ICT and their knowledge of effective learning environments were important elements when planning sessions. More effective teachers used explanations and modelling, choosing a more student centred approach which involved collaborative working, enquiry and decision making. Prensky (2001: p. 2) suggests that today's students are very different; referring to them as 'Digital Natives', he argues that 'one of the biggest problems facing education today relates to instructors who are struggling to teach a population that speaks an entirely new language'. 
'Teacher confidence is directly affected by levels of personal access to ICT, levels of available technical support and the amount and type of training available, all of which can be seen as barriers to ICT themselves.'

(Ertmer, 1999: p. 57)

As part of Cert Ed unit 2, an initial workshop is scheduled which provides an opportunity to explore and download freely available online resources (e.g. National Learning Network, Excellence Gateway, Further Education National Consortium [FENC]). Trainees are also introduced to resources (such as Flip videos, digital cameras, mobile phones) as well as free software (including Tarzia Formulator, Hot Potatoes, Puzzle Maker, Excel Domino Generator). Russell and Bradley (1997) suggest that teachers are afraid of what can go wrong when using technology, which in turn creates a barrier to using technology. They go on to suggest that the only way to remove this barrier is to build confidence. Embedding opportunities to explore and experiment with resources early in the Cert Ed programme helps trainees to overcome this lack of confidence and introduces them to the wide range of resources available and the possible benefits of using the resources. This view is upheld in the work of Cox et al (1999) which highlights that e-learning staff development needs to ensure that teachers are made aware of the benefits of using ICT.

This initial introduction to resources is further developed within unit 4. As part of the assessment for this module, trainees are required to develop a poster or leaflet for use as an assessment tool with their own learners. Scheduled workshops provide opportunities for trainees to develop their poster/leaflet and experiment with technology (such as Microsoft Publisher), incorporating images and using online survey tools. This provides opportunities for trainees to practise skills in the use of technology and familiarise themselves with the procedures which need to be followed as discussed in the work of Russell and Bradley (1997).

For unit 5, trainees are asked to carry out research on the different theories of learning with specific topics being allocated to different individuals within the group. This provides opportunities to practise skills in conducting internet research and using Microsoft Word to produce a handout which summarises the findings. Their findings are then presented to their peers and uploaded to the Virtual Learning Environment (VLE) for group reference enabling all group members to benefit from the research undertaken individually. Snoeyink and Ertmer (2001) noted the importance of practitioners seeing purpose in using technology in their teaching, and suggest that this is achieved through focused training which specifically shows teachers how technology can help them in their own individual situations. Research undertaken by Jung (2005) suggests that using ICT within teacher training can provide opportunities for trainee teachers to promote their ICT pedagogy integration and discuss the approaches taken and suggest that 'teachers are, likely to benefit by actively experiencing ICT skills as a learner' (ibid: p. 6).

Unit 6 is delivered across year 1 using a blended approach. The VLE is used to support delivery of this and other modules. A number of tasks are uploaded to the VLE for completion by specific dates. All tasks are directly linked to the module assessment outcomes and provide opportunities for trainees to develop their classroom practice. The tasks require trainees to experiment with a new resource or questioning technique; evaluate effectiveness of a resource or approach; observe others teach their subject; participate in a blog; participate in online communities of practice (relevant to specialist areas); carry out research on key philosophical issues affecting education in own specialist area; and formally present findings to their peer group using Microsoft PowerPoint. The presentation is peer reviewed and is an integral part of the summative assessment for the module. The discussions are recorded using a simple Universal Serial Bus (USB) voice recorder and uploaded to VLE for further reference.

The unit 6 assessment includes an evaluation of how working with a mentor and other experienced teachers or communities of practice has impacted on their own practice and deepened understanding of teaching in their specialist area. In face-toface sessions, group members discuss benefits of observing another tutor and share findings with the wider group, leading to deeper discussion of teaching and learning techniques and how these can be applied with their own learners. 'Teachers typically have limited opportunities to work with others who can support them as they learn new ways of teaching' (Swafford, 1998: p. 54). Swafford also discussed - in relation to Joyce and Showers' theories on mentoring - how peer coaching in this way helps teachers to become more confident and develop new techniques. Through the opportunities provided to discuss and share outcomes from experimenting with new resources or questioning techniques, group members are able to share their resources and receive feedback with some group members taking the opportunity to deliver 'micro-teaching sessions' to peers to receive feedback on resources created. Joyce and Showers (1996), who introduced a model of peer coaching, suggest that teachers who shared aspects of their teaching were more likely to practise new skills. Face-to-face sessions also include a number of workshops which provide opportunities to explore new resources and download and adapt suitable ones for individual use or to develop existing resources.

The Professional Development Record (PDR) (which includes reflective statements for each of the modules, tutorial reviews and self reflection against teaching standards) is held on the VLE and by accessing the VLE trainees are able to edit and update their PDRs online. They are able to upload assignments and lesson observation feedback into individual folders to which only they and the personal tutor have access. By the end of Year 1, trainees are generally competent in using word processing and presentation software; they will have experimented with a number of resources; will have participated in at 
least one blog/online discussion forum; have used the VLE to upload and download resources; and should also be able to use common search engines effectively to carry out research.

Within Year 2 of the Cert Ed programme the focus is on developing pedagogical knowledge and building confidence in using e-learning tools. As an initial introduction to unit 7, the group is introduced to online research techniques which involve using metasearch engines (such as Ixquick, Dogpile and Browsys) and refining search criteria to obtain reliable results. It is at this stage in the programme that the first e-learning session is formally introduced. The eSkills programme is a further development of the Further Education Resources for Learning (FERL) Practitioners' Programme (FPP) Transforming Teaching and Learning with ILT: this staff development programme was introduced by the British Educational Communications and Technology Agency (BECTA) in 2003. A combination of the FERL Practitioner resources and the eSkills resources are used to support this initial e-learning session which focuses on the pedagogical benefits of e-learning and different approaches taken rather than just the technological aspects involved. The key message is that using technology without considering the pedagogical benefits will not improve the quality of delivery but using new types of resources can satisfy different learning preferences whilst presenting different ways of accessing information (FPP, 2003). This could include online guidance, assessment and recording of progress, traditional learning or support. According to FERL (2003) the use of information learning technologies can develop thinking skills, support differentiation and motivate learners. Focusing on the teaching principles rather than the resources can empower teachers to be more creative with existing resources. Higgins (2009) suggests that where teachers choose to adopt the use of technology this should be part of a process of enquiry. If technology is used merely to replace problematic practice then the effect may be minimal. The rationale for the effective integration of technology should be to support teaching and learning through specific application of the technology.

Unit 9 requires trainees to participate in an online discussion as an integral part of the assessment process. An initial 'Netiquette' session introduces 'do's' and 'don'ts' involved in participating in online discussion or chat. Exemplar discussion questions are set up on the VLE to enable trainees to participate and also to experience problems associated with disruptive participants. For the assessed element, the group are required to discuss key aspects of professionalism in the context of the Lifelong Learning Sector; ways in which equality of opportunity and respect for diversity can be built into teaching and learning practice; the contribution of learning to personal development, economic growth and community regeneration; and the implications and impact of government policies on teaching and learning in the Lifelong Learning Sector. This assessed element takes place over a number of weeks, and is followed by a verbal discussion and summary of findings from each group. These discussions are digitally recorded and uploaded to the VLE for group members to refer back to when they are producing final written assignments.

The Cert Ed course offers a number of option units, one of which is IT and the Teacher. The assessment for this unit requires trainees to develop a resource which makes use of technology; pilot the resource in the classroom and obtain learner feedback; and be observed using the resource. Not all group members choose to select this optional unit but workshops are provided for the whole group allowing them to experiment with different resources and develop their own resources. The unit also includes an introduction to: Xerte Toolkits (a tool for creating accessible interactive learning materials); Access Apps (a range of open source and freeware applications); podcasting; using video clips; using classroom voting systems; making resources interactive by using drop-down boxes in Word; interactive PowerPoint presentations; embedded videos and using Hot Potatoes (a quiz generation tool), or other similar tools to create interactive quizzes.

Some of the resources developed by trainees undertaking this unit include using a Text Wall with learners (which is a means of enabling learners to interact using text messaging); using online questionnaires (such as Survey Monkey) to obtain learner feedback after each unit of assessment; developing interactive spreadsheets; developing interactive quizzes; using Xerte and classroom voting systems; embedded video clips; using mobile phones to capture images for assessment and uploading to an e-portfolio; using mobile phones to record practice; developing interactive PowerPoint presentations; developing a course area on the VLE.

The initial e-learning session introduced as part of unit 7 and the workshops to support the IT and the Teacher option also link to requirements of Cert Ed unit 8 which focuses on curriculum design and principles of equality, diversity and inclusive practice. The e-learning sessions introduce trainees to the wide range of resources available through JISC Techdis which focus on accessibility and 'making mainstream practices more inclusive'; JISC Techdis are the 'leading advisory service on technology and inclusion' (JISC Techdis, 2011). The two-part Equality and Diversity Tool developed by Liz Pichon for the East of England Centre of Excellence in Teacher Training (EECETT) enables trainees to 'review their existing resources and self assess their current teaching and learning practice' (EECET'T, 2009).

\section{Conclusion}

Embedding eSkills within the ITT programmes has enabled trainees to become more confident in their own use of ICT and provides opportunities to ensure that trainees are aware of the benefits of using ICT as highlighted in the work of Cox et al (1999). A qualitative evaluation of the eSkills programme identified one of the drivers influencing staff to improve their elearning skills was the belief that students are more confident and competent with technology than their teachers (Bone, 2011). In his video clip, $21^{\text {st }}$ Century Learning, Professor Stephen Heppell makes a comparison between the $21^{\text {st }}$ Century 
Learner and his or her teacher. He compares the learner to the front runner in a game of American football whilst his or her teacher are described as the rest of his or her team trying to catch up - both are in the pursuit of the same goal but the learner is noticeably ahead in the use of technology. This stresses the importance for teachers to engage in the utilisation of new technologies in an effort to improve teaching and learning and to keep up to date with learners' expectations, as identified in the FERL Practitioners' Programme A Skilled Practitioner With Few IT Skills Can Produce Imaginative, Creative And Effective Resources By Focusing More On The Teaching Principles Than On The Technology (FPP, 2003). Although it is important to ensure that practitioners have good IT skills it is vital to ensure that they also have the pedagogic skills to recognise how to use technology effectively. McGhee and Kozma (2001) as cited in Hennessy et al (2003: p. 3) categorised the teacher's role when planning to integrate ICT as: 'instructional designer, technical (trainer), enabling advisor/facilitator, monitoring and assessment specialist. This requires the teacher to build on their knowledge of 'established classroom practice', (Hennessy, Deaney and Ruthven, 2003: p. 35) utilising a range of strategies to develop paired and small group activities which encourage thinking skills and provide opportunities for whole group interaction and discussion in order to consolidate learning.

In a study of teacher education institutions in Scotland, Simpson et al (1999: p. 257) found the lack of pedagogy in IT training to be a problem for students undergoing ITT: 'The trainee teachers clearly felt that their tutors had failed to deal extensively or as effectively as they would have wished with the key factors associated with the pedagogical use and management of ICT, e.g. more involvement of learners through participation in collaborative group work, paired activities, discussions, active investigation and a reduction in the more formal didactic teaching approach (Hennessy, Deaney and Ruthven 2003; Jung, 2005; Cox and Webb, 2004). However it has been shown that embedding eSkills in IT'T can enable students to develop their skills and reach a confident level in order to use e-learning to enhance their teaching.

In research undertaken by Hennessy, Deaney and Ruthven (2003) into pedagogic strategies for using ICT to support teaching and learning, they reported that the decrease in teacher direction enables the teacher to take on the role of facilitator and enabler which in turn encourages more involvement between teacher and learner. Using examples of real educators and learners using technology to support learning in their own classrooms (Jung, 2005) provides opportunities to discuss strategies and techniques and enables trainees to reflect on the advantages/disadvantages of using different technologies within specific subject areas. Bowes (2003; as cited in Jung, 2005) suggests that to use technologies effectively it is important that teachers are provided with opportunities to reflect on the potential of the technologies. Observation of trainees' classroom practice demonstrates a growing confidence in using new technologies within the taught sessions. Providing training in the use of technologies alongside opportunities for experimentation enables teachers to develop confidence. Feedback obtained from DTLLS/Cert Ed/PGCE end of year evaluations and observation of trainees' teaching practice confirms this view, but requires further quantitative research to fully substantiate this.

\section{References}

Alexander, 1992 as cited in Cox, M., Webb, M., et al (2004) An Investigation of the Research Evidence Relating to ICT Pedagogy. Report to the DfEs (January 2004) Available from http://www.pgce.soton.ac.uk/ict/NewPGCE/PDFs/CoxWebbLitRevPedagogy2004.pdf [accessed 14 September 2011].

Bone, C. (2011) A Critical Evaluation of the Factors which Influence the Development of a Successful e-Learning Staff Development Programme. M.A. Anglia Ruskin University.

Bowes, J. (2003) as cited in Jung, I. (2005) 'ICT-Pedagogy Integration in Teacher Training: Application Cases Worldwide', Educational Technology Society, 8 (2), 94-101.94 ISSN.

Collis and Jung, as cited in Jung, I. (2005) 'ICT-Pedagogy Integration in Teacher Training: Application Cases Worldwide', Educational Technology Society, 8 (2), 94-101.94 ISSN.

Cox, M., Preston, C., Cox, C. (1999) What Factors Support or Prevent Teachers from using ICT in the Primary Classroom. Paper presented at the British Educational Research Association Annual Conference. University of Sussex at Brighton. (2-5 September 1999). Available from http://www.leeds.ac.uk/educol/documents/00001304.htm [accessed 29 July 2011].

Cox, M., Webb, M. (2004) A Review of Pedagogy Related to Information Communications Technology. 'Technology, Pedagogy and Education' Vol. 13, No. 3, 2004. http://dx.doi.org/10.1080/14759390400200183

Cox, M., Webb, M., et al (2004) An Investigation of the Research Evidence Relating to ICT Pedagogy. Report to the DfES (January 2004) Available from http://www.pgce.soton.ac.uk/ict/NewPGCE/PDFs/CoxWebbLitRevPedagogy2004.pdf [accessed 14 September 2011].

Department for Education and Skills (2006) Further Education: Raising Skills, Improving Life Chances [Online] Available from www.eauc.org.uk/sorted/files/fe_white_paper_1.pdf [accessed 29 July 2011].

East of England Centre of Excellence in Teacher Training (EECETT) (2008/2009) Research Publications, Equality and Diversity in the Classroom [Online] Available from http://www.acer.ac.uk/eecett_researchpub.php [accessed 31 July 2011].

Ertmer, P.E.A. (1999) 'Examining Teachers' Beliefs About the Role of Technology in the Elementary Classroom', Journal of Research on Computing in Education, 32 (1), pp. 54-72.

FERL Practitioners' Programme (FPP) (2003) [Online] Available from http://www.clydebank.ac.uk/signol/electures/FERL/FPP/mainmenu.htm [accessed 29 July 2011].

Haddad, W.D. 2003 as cited in Jung, I. (2005) 'ICT-Pedagogy Integration in Teacher Training: Application Cases Worldwide', Educational Technology Society, 8 (2), 94-101.94 ISSN Available from http:// citeseerx.ist.psu.edu/viewdoc/download?doi=10.1.1.103.3805 [accessed 14 September 2011].

Hennessy, S., Deaney, R., Ruthven, K. (2003) 'Pedagogic Strategies for Using ICT to Support Subject Teaching and Learning: An Analysis Across 15 Case Studies', University of Cambridge Faculty of Education Research Report 03/1(2003) Available from http://www.educ.cam.ac.uk/research/projects/istl/\#warpict [accessed 24 September 2011].

Heppell, S. (2008) '21 st Century Learners' [Video] [Online] Available from

http://tlp.excellencegateway.org.uk/resource/EL_CD_ROM/gettingstarted/technologyandth/index.html [accessed 28 July 2011]. 
Higgins, S. (2009) The Benefits of Information and Communication Technologies for Learning: Beware of Geeks Bearing Gifts? Seminar presented at the General Teaching Council Teaching and Learning Conference 2009. Available from http://www.gtce.org.uk/197686/201094/ict_steve_higgins [accessed 24 September 2011].

JISC Executive (2003) e-Learning Pedagogy Programme. [Online] Available from http://www.jisc.ac.uk/elearning_pedagogy.html [accessed 29 July 2011]. JISC (2008) Tangible Benefits of e-Learning: Does Investment yield Interest? [Online] Available from http://www.jisc.ac.uk/media/documents/publications/bptangiblebenefitsv1.pdf [accessed 29 July 2011].

JISC Executive (2009a) Responding to Learners Pack, Guide for Institutional Managers. [Online] Available from

http://www.jisc.ac.uk/publications/programmerelated/2009/respondingtolearners.aspx [accessed 29 July 2011].

JISC Techdis (2011) Resources [Online] Available from http://www.jisctechdis.ac.uk/techdis/resources/detail/resources/resources_handy_summary [accessed 31 July 2011].

Joyce, B., Showers, B. (1996) 'The Evolution of Peer Coaching'.Educational Leadership, 53 (6): 12-16.

Jung, I. (2005) 'ICT-Pedagogy Integration in Teacher Training: Application Cases Worldwide', Educational Technology Society, 8 (2), $94-101.94$ ISSN.

McGhee and Kozma (2001), as cited in Hennessy, S., Deaney, R., Ruthven, K. (2003) 'Pedagogic Strategies for Using ICT to Support Subject Teaching and Learning: An Analysis Across 15 Case Studies', University of Cambridge Faculty of Education Research Report 03/1(2003) Available from http://www.educ.cam.ac.uk/research/projects/istl/\#warpict [accessed 24 September 2011].

Prensky, M. (2001) 'Digital Natives, Digital Immigrants', On the Horizon 9 (5): 1-6. http://dx.doi.org/10.1108/10748120110424816

Quality Assurance Agency for Higher Education (2008) Outcomes from Institutional Audit, Institutions' Support for e-Learning. [Online] Available from www.qaa.ac.uk/reviews/institutionalAudit/outcomes/series2/SupportforElearning08.asp [accessed 27 July 2010].

Russell, G., Bradley, G. (1997) Teachers' Computer Anxiety: Implications for Professional Development, 'Education and Information Technologies', 2 (1), pp. 17-30. http://dx.doi.org/10.1023/A:1018680322904

Simpson, M., Payne, F., Munro, R., Hughes, S., Lynch, E. (1999) 'ICT in Initial Teacher Education in Scotland'. Northern College, Department of Educational Research.

Snoeyink, R., Ertmer, P. (2001) 'Thrust into Technology: How Veteran Teachers Respond', Journal of Educational Technology Systems, 30 (1), pp. 85-111. http://dx.doi.org/10.2190/YDL7-XH09-RLJ6-MTP1

Swafford, J. (1998) 'Teachers Supporting Teachers Through Peer Coaching', Support for Learning. 13 (2), pp. 54 - 58, Blackwell Publishing. http://dx.doi.org/ $\underline{10.1111 / 1467-9604.00058}$

The Higher Education Funding Council for England (2009) Enhancing Learning and Teaching Through the use of Technology. A Revised Approach to HEFCE's Strategy for e-Learning. [Online] Available From http://www.hefce.ac.uk/Pubs/hefce/2009/09_12/[accessed 29 July 2011].

Appendix 1

eSkills Modules

Module 1: An Introduction to e-learning

This module provides a better understanding of the application of e-learning in the context of an individual's own teaching practice.

Module 2: e-resources and copyright

This module explores some of the JISC-licensed and nationally funded e-resources available. It also highlights some legal issues affecting practitioners in the context of learning and teaching, particularly those of Intellectual Property Rights and Copyright.

Module 3: Creating Interactive Resources (1) (Microsoft Word)

This module enables practitioners to create interactive learning resources using Microsoft Word.

Module 4: Designing an Inclusive Curriculum

This module highlights the strategies practitioners can undertake to ensure that materials are created and presented in a more accessible manner.

Module 5: Creating Interactive Resources (2) (Microsoft PowerPoint)

This module enables practitioners to create interactive learning resources using Microsoft PowerPoint.

Module 6: Online Communications and e-Tutoring

This module explores the use of online communication tools (including Web 2.0 applications) in the context of tutor support and includes consideration regarding email, discussion tools, wikis and blogs.

Module 7: e-Assessment

This module explores the design of effective e-assessments as well as demonstrating how to create effective e-assessment content.

\section{Module 8: Learning Platforms and Going Mobile}

This module provides an overview of learning platforms and mobile technologies currently available whilst highlighting their application to learning and teaching.

Module 9: e-Safety and Safeguarding

This module focuses on safeguarding and provides staff with the skills to safeguard themselves and students when using technology.

Appendix 2

Mapping eSkills Modules to DTLLS/Cert Ed/PGCE Units of Assessment

\begin{tabular}{|l|l|}
\hline $\begin{array}{l}\text { DTLLS/Cert Ed/PGCE Unit of } \\
\text { Assessment }\end{array}$ & eSkills Modules \\
\hline Unit 2: Planning and Enabling Learning & $\begin{array}{l}\text { Module 2: e-resources and copyright } \\
\text { Module 4: Designing an Inclusive Curriculum }\end{array}$ \\
\hline
\end{tabular}




\begin{tabular}{|c|c|}
\hline & Module 9: e-Safety and Safeguarding \\
\hline Unit 4: Enabling Learning and Assessment & $\begin{array}{l}\text { Module 1: An introduction to e-learning } \\
\text { Module 2: e-resources and copyright } \\
\text { Module 4: Designing an Inclusive Curriculum } \\
\text { Module 6: Online Communications and e-Tutoring } \\
\text { Module 7: e-Assessment } \\
\text { Module 8: Learning Platforms and Going Mobile }\end{array}$ \\
\hline $\begin{array}{l}\text { Unit 5: Theories and Principles of Planning } \\
\text { and Enabling Learning }\end{array}$ & $\begin{array}{l}\text { Module 1: An introduction to e-learning } \\
\text { Module 2: e-resources and copyright } \\
\text { Module3: Creating Interactive Resources (1) (Microsoft Word) }\end{array}$ \\
\hline Unit 6: Subject Specific Teaching & $\begin{array}{l}\text { Module 2: e-resources and copyright } \\
\text { Module 3: Creating Interactive Resources (1) (Microsoft Word) } \\
\text { Module 4: Designing an Inclusive Curriculum } \\
\text { Module 5: Creating Interactive Resources (2) (Microsoft PowerPoint) } \\
\text { Module 6: Online Communications and e-Tutoring } \\
\text { Module 8: Learning Platforms and Going Mobile } \\
\text { Module 9: e-Safety and Safeguarding }\end{array}$ \\
\hline $\begin{array}{l}\text { Unit 7: Reflective Practice and Professional } \\
\text { Development }\end{array}$ & $\begin{array}{l}\text { Module 1: An introduction to e-learning } \\
\text { Module 2: e-resources and copyright } \\
\text { Module 6: Online Communications and e-Tutoring } \\
\text { Module 7: e-Assessment } \\
\text { Module 8: Learning Platforms and Going Mobile }\end{array}$ \\
\hline $\begin{array}{lll}\text { Unit 8: Curriculum } & \text { Development for } \\
\text { Inclusive Practice } & & \end{array}$ & $\begin{array}{l}\text { Module 2: e-resources and copyright } \\
\text { Module 3: Creating Interactive Resources (1) (Microsoft Word) } \\
\text { Module 4: Designing an Inclusive Curriculum }\end{array}$ \\
\hline Unit 9: Subject Specific Teaching & $\begin{array}{l}\text { Module 6: Online Communications and e-Tutoring } \\
\text { Module 7: e-Assessment } \\
\text { Module 8: Learning Platforms and Going Mobile } \\
\text { Module 9: e-Safety and Safeguarding }\end{array}$ \\
\hline Option Unit: IT and the Teacher & $\begin{array}{l}\text { Module 1: An introduction to e-learning } \\
\text { Module 2: e-resources and copyright } \\
\text { Module 3: Creating Interactive Resources (1) (Microsoft Word) } \\
\text { Module 4: Designing an Inclusive Curriculum } \\
\text { Module 5: Creating Interactive Resources (2) (Microsoft PowerPoint) } \\
\text { Module 6: Online Communications and e-Tutoring } \\
\text { Module 7: e-Assessment } \\
\text { Module 8: Learning Platforms and Going Mobile } \\
\text { Module 9: e-Safety and Safeguarding }\end{array}$ \\
\hline
\end{tabular}

